\title{
DIRECTIVE 2010/64/EU OF THE EUROPEAN PARLIAMENT AND OF THE COUNCIL ON THE RIGHT TO INTERPRETATION AND TRANSLATION IN CRIMINAL PROCEEDINGS: TRANSPOSITION STRATEGIES WITH REGARD TO INTERPRETATION AND TRANSLATION
}

\author{
Erik Hertog \\ erik.hertog@outlook.be \\ KU Leuven, Belgium
}

\begin{abstract}
It is difficult to overestimate the importance of Directive 2010/64/EU on the right to interpretation and translation in criminal proceedings. It is the first directive under the Lisbon Treaty, the first directive in the field of Justice (up till then one had recourse to framework decisions only), the first directive on language since the founding treaties of the EU and, of course, the first directive on issues of translation and interpretation. In this contribution we will discuss the relevant policy-making history leading up to the Directive, highlight the main challenges the Directive presents to the Member States that need to transpose this binding Directive into their own legislation and practice and, finally, suggest a number of strategies and policies that could help the transposition process, both in the short and long term.
\end{abstract}

\section{Resumen}

Resulta difícil sobreestimar la importancia de la Directiva 2010/64/UE del Parlamento Europeo y del Consejo, de 20 de octubre de 2010, relativa al derecho a interpretación y a traducción en los procesos penales. Se trata de la primera directiva emanada del Tratado de Lisboa, de la primera directiva en el ámbito de la justicia (hasta entonces se recurría solamente a las decisiones marco), de la primera directiva sobre lenguas desde los tratados fundacionales de la UE; y, por supuesto, de la primera directiva sobre traducción e interpretación. En la presente publicación, se analiza el historial 
de decisiones políticas relevantes que han llevado a la aprobación de la Directiva, se destacan los principales retos que presenta la Directiva para los Estados Miembros que tienen que transponer esta norma de obligado cumplimiento a su propia legislación y ejercicio; y, finalmente, se sugieren una serie de estrategias y políticas que pueden ser útiles durante el proceso de transposición, tanto a corto como a largo plazo.

Keywords: Directive. Legal interpreting. Legal translation.

Palabras clave: Directiva. Interpretación judicial. Traducción judicial

Manuscript received on May 10, 2014 and accepted for publication on July 22, 2014. 


\section{The background}

There are a number of fundamental reasons why the EU - the Commission, Council and Parliament - has evolved over the years from a predominantly political and socio-economic enterprise and become increasingly proactive in the area of justice. It was the Maastricht Treaty (1993) which first introduced justice and home affairs as "matters of common interest" for the EU while the Amsterdam (1999) and Nice (2000) Treaties set out the ambition to shape the EU into "an area of freedom, security and justice". The prime political expression of this development is the Charter of Fundamental Freedoms of the European Union (2000) which, in Chapter VI Justice, Articles 47 and 48 addresses the "Right to an effective remedy and to a fair trial" and the "Presumption of innocence and right of defence". ${ }^{1}$

In this so-called 'third pillar' of the EU, the preeminent objectives were cooperation and mutual trust between the Member States and mutual recognition of judicial decisions. However, it was quite clear from the beginning that such mutual confidence by the authorities as well as citizens in the legal systems of the Member States ultimately rests on reliable communication. This explains why from the start of this development, the importance of competent interpretation and translation in the area of justice was highlighted.

Secondly, cooperation was also urgently needed in the face of new threats (terrorism, organized crime, human trafficking, etc.). The abolition of controls at internal frontiers within the EU, the enlargement of the Union, the dramatic events of 11 March 2004 in Madrid and 7 July 2005 in London, reinforced the need for further cooperation in the area of criminal justice. This objective materialized most prominently in a number of 'Framework Decisions' on e.g. obtaining evidence in criminal matters, human trafficking, money laundering, child pornography, terrorism, etc. A framework decision was the legal instrument available to the Commission under the so-called

1. http://www.europarl.europa.eu/charter/pdf/text_en.pdf This 'genesis' survey of Directive 2010/64/EU is based on a selection of relevant primary documents only and contains no further references to publications on EU policy, law or interpreting. 
'third pillar' and it required the unanimous approval of all Member States in the EU Council. No doubt one of the most effective of these, and one that will return later in our discussion of Directive 2010/64/EU, is the Council Framework Decision of 13 June 2002 on the European Arrest Warrant and the surrender procedures between Member States, which replaced the divergent extradition procedures within the EU, making it easier, for example, for a Belgian national suspected of a criminal offence in Spain to be surrendered and stand trial there. ${ }^{2}$ The issue of confidence in one another's legal procedures is highlighted here in the following observation on the reliability of communication:

Few Member States accept an EAW in a language other than their official language. This extends to requests for supplementary information [...]. The scarcity of translation capacity in some Member States, associated costs, difficulties in translation into some of the less common languages in short periods of time or the bad quality of translations are recurrent arguments in this regard. (Council of the European Union 26 May 2009 Crimorg 55; Cope 68; EJ 24; Eurojust 20)

On the other hand, there was always the understanding that steps taken to enhance the more efficient execution of justice needed to be counterbalanced by the safeguarding of fundamental and citizens' rights. A third reason therefore was the divergence among the Member States and their tenuous relationship vis-à-vis the European Convention for the Protection of Human Rights and Fundamental Freedoms (ECHR), particularly Article 5.2 ("Everyone who is arrested shall be informed promptly, in a language which he understands, of the reasons for his arrest and of any charge against him.") and Article 6.3 ("Everyone charged with a criminal offence has the following minimum rights: a. to be informed promptly, in a language which he understands and in detail, of the nature and cause of the accusation against him; [...] e. to have the free assistance of an interpreter if he cannot understand or speak the language used in court."). ${ }^{3}$ The need for better compliance with the Convention manifested itself uncomfortably in the string of decisions by the European Court of Human Rights (ECtHR) against EU Member States and it was therefore one of the great challenges of any EU-initiative in this area to position itself in the future much more in line with the requirements of the Convention. ${ }^{4}$ After

2. OfficialJournal 18.07.2002 and http://eur-lex.europa.eu/legal-content/EN/TXT/?uri=OJ:L: 2002:190:TOC

3. http://www.echr.coe.int/Documents/Convention_ENG.pdf

4. Some noteworthy cases are: Luedicke, Belkacem \& Koc v. Germany (1978), Artico v. Italy (1980), K. v. France (1983), Kamasinski v. Austria (1989), Brozicek v. Italy (1989), Cuscani v. United Kingdom (2002), Conka v. Belgium (2002), Ucak v. the United Kingdom (2002), Lagerblom v. Sweden (2003), Coban v. Spain (2003 and 2006), Husain v. 
all, the procedural rights of all European citizens should be protected across languages, cultures or impediments. Interpreters and translators therefore constituted a critical link in the communication whenever and wherever an EU citizen became involved in the legal system of another Member State.

This concern was obviously also sparked by the increased mobility of citizens throughout Europe. They may go on holiday, study or seek employment in another Member State and occasionally they find themselves involved in legal problems in that country. According to Eurostat, ${ }^{5}$ the total number of foreigners, including citizens of other EU Member States and non-EU citizens residing in an EU country in 2013, was 20,370,366. In Germany 7,696,413 foreign residents were recorded, in Spain 5,072,680, in the United Kingdom $7,696,413$, in Italy 4,387,721 and in France 4,089,051. In this envisaged "area of freedom, security and justice" the EU needed to ensure that the rights of its citizens, be they victims, defendants or prisoners were protected, including when crossing borders. EU citizenship should carry with it the right to a fair trial no matter where one is in the Union. However, citizens were facing practical and legal difficulties when they needed to exercise the rights they have at home in another Member State. One cannot have a fair trial if the accused does not understand the language of the proceedings. EU citizens should never feel that their rights are weakened because they left home. In short, justice needed to be guaranteed across borders.

In addition, there has always been the cost issue with regard to legal interpreting and translation (LIT). Member States were indeed spending substantial amounts of money on LIT without any guarantees whatsoever that quality was actually ensured. In the course of the negotiations on the second Framework Decision proposal (cfr. infra), the Commission published an Impact Assessment Study estimating the cost of LIT in the Member States (Commission staff working document, Brussels, 8.7.2009; SEC(2009) 915). For Italy, for example, the cost of interpretation in 2006 (number of criminal proceedings involving non-nationals $\mathrm{x} € 200$ ) was assessed at $€ 11,826,200$, the cost of translation (30 pages on average $\mathrm{x}$ anywhere between $€ 255$ and $€ 1500)$ at between $€ 15,078,045$ and $€ 88,696,500$. For Spain, it was assessed at $€ 19,485,200$ for interpreting and somewhere between $€ 24,843,630$ and

Italy (2005), Hermi v. Italy (GC 2006), Isyar v. Bulgaria (2008), Panasenko v. Portugal (2008), Baka v. Romania (2009), Diallo v. Sweden (2010), Khatchadourian v. Belgium (2010), Mann v. the UK and Portugal (2011) etc. For an interesting presentation on the main issues highlighted by these cases, see the contributions by James Brannan of the ECtHR to the EULITA TRAFUT workshops at http://www.eulita.eu

5. http://epp.eurostat.ec.europa.eu 
$€ 146,139,000$ (again depending on the cost per page) for translations. The point is not so much whether these figures were absolutely reliable and correct, but that LIT in criminal proceedings in any EU Member State involved a considerable cost, though one that came without quality assurances. This is clearly an untenable situation that, at least in the eyes of the Commission, needed to be remedied.

In sum, the provision of inadequate LIT in criminal proceedings was seen as an infringement of fundamental human rights as well as undermining the rights of EU citizens and residents in the EU. The situation jeopardized the principle of mutual trust between Member States and cost the system dearly in terms of money, time and quality of justice. In the end, it prevented all legal stakeholders from doing the professional job they wanted and needed to do. But given the insufficient numbers of trained LITs in the Member States, the very different quality standards, the lack of compatible national registers as well as the lack of interdisciplinary guidelines for best practices, the need to include LIT in any initiative ensuring stronger procedural safeguards in criminal proceedings throughout the EU became an urgent priority.

\section{The preliminary stages}

In order to understand the content and remit of Directive 2010/64/EU, it may be useful to retrace succinctly some of the crucial steps along the road. Following the Amsterdam Treaty (1999), the European Council laid down the priorities for the Justice and Home Affairs policy areas in three subsequent five-year action programmes, i.e. 'Tampere', 'The Hague' and 'Stockholm'. As indicated above, the issue of access to and quality of interpreting and translation featured right from the beginning as one of the fundamental rights and procedural safeguards to be guaranteed. Consequently, the Action Grants call in the first Grotius programme included LIT and invited projects in this field. The first important and still very relevant project was Aequitas (Grotius project 98/GR/131), which described the required LIT competences, training, code of conduct and guidelines of good practice as well as good working arrangements with other legal professionals. ${ }^{6}$ It was followed by the Aequalitas project (Grotius project 2001/GRO/015), which sought to disseminate these recommendations throughout the EU.

In 2002, the EU Commission embarked on its own initiative on 'Procedural Safeguards in Criminal Proceedings' with a Consultation Paper,

6. All EU projects on LIT can be consulted on the EULITA website http://www.eulita.eu. See under 'LIT Materials'. 
followed by a Questionnaire for the Member States, a seminar on the Quality of Justice and a Hearing on the Consultation Paper. This consultation round led to a Discussion Paper and a Meeting of Experts, resulting in the publication of a Green Paper on Procedural Safeguards for Suspects and Defendants in Criminal Proceedings throughout the European Union in February 2003 (Brussels, 19.2.2003, $\operatorname{COM}(2003) 75$ final). ${ }^{7}$

It should be noted that the scope of the Green Paper was much wider than the current Directive. It actually encompassed a package of five procedural rights: the right to legal assistance and representation both before and at the trial; the right to a competent, qualified interpreter and/or translator so that the accused knows the charges brought against him/her and understands the procedure; the right to consular assistance to foreign detainees; the right to information on rights, including written notification of rights (the letter of rights'); and proper protection for especially vulnerable categories, i.e. the rights of persons who cannot understand or follow the proceedings.

This Green Paper was welcomed by the LIT community as it contained virtually everything - from training and certification to registration, code of ethics and working arrangements with the legal professionals - that had been proposed in the Grotius projects, which clearly had inspired the section on LIT: Member States would be required to have a system to train LITs and a system for their certification, including a registration system, establish continuous professional development (CPD), have a system for monitoring the provision and quality of LIT, have a code of ethics and guidelines for good professional working practices and offer training to judges, public prosecutors and solicitors on how to work with LITs. Many other stakeholders such as the CCBE (Conseil des Barreaux Européens), NGOs (Fair Trials International, Amnesty International, etc.), even the European Parliament welcomed the proposals as well. However, some Member States were sceptical, some downright negative: they felt the ECHR was a sufficient legal instrument to deal with these issues and that, following the subsidiarity principle, these matters belonged to the Member States' prerogatives. They also felt that such an initiative would entail an unnecessary, unwanted and overhasty harmonisation of criminal law across the Member States and they were greatly concerned about the financial implications of the proposals.

Nevertheless, the EU Commission moved forward on the issue with the presentation of a Proposal for a Council Framework Decision on certain

7. http://eur-lex.europa.eu/legal-content/EN/TXT/PDF/?uri=CELEX:52003DC0075\&from $=\mathrm{EN}$ 
Procedural Rights in Criminal Proceedings throughout the European Union (COM (2004) 328 final -28.4.04). ${ }^{8}$ It is important to repeat that a framework decision was the most binding legal instrument available in matters of justice and that it needed unanimous approval from the Member States. The Proposal continued the 'package' approach, aiming to establish common minimum standards in the same five areas as the Green Paper. With regard to LIT, the Proposal repeated fundamental principles such as the fact that interpretation should be "free of charge to the suspected person", also available to "persons with hearing or speech impairments" and that it should be provided as soon as possible "after it has come to light that the suspect does not understand the language of the proceedings" (Article 6). Interestingly, the Proposal already included "police questioning" and "meetings between the suspect and his lawyer" as specific instances for attention. Free translation of the documents which the defendant "needs to understand in order to have a fair trial" had to be provided (Article 7), though the article did not identify them and put the onus "on the competent authorities to decide what documents shall be provided in translation but the suspect's lawyer has the right to request further documents in translation". Article 8 on the 'accuracy' of the translation and interpretation, however, was very vague. All quality safeguards on LIT mentioned in the Green Paper (training, certification, a register, CPD, codes, working arrangements, etc.) had now been watered down to the mere requirement that "The standard of interpretation and translation must be good enough" and if not,

lawyers, judges, defendants or anyone else involved in criminal proceedings who becomes aware that the required standard of interpretation has not been met by a particular interpreter or in a particular case may report it so that a replacement translator or interpreter may be provided.

Remarkably though, for sign language Article 6 required that "it is important that only qualified and experienced sign language interpreters are assigned for court proceedings or police interviews". Article 9 required audio or video recording of the proceedings as a "method of verification" of the accuracy of the interpretation and Article 16 instituted a duty to collect data to monitor the provision of LIT (the number of persons for whom the services of an interpreter or translator was required, nationalities, languages, etc.). Apart from the comprehensiveness of the Proposal, it is these two articles, no matter how valuable (Article 9) or useful (Article 16) that would play a decisive role in its future fate.

8. http://www.ecba.org/extdocserv/projects/ps/Latest_Council_text.pdf 
In the course of the difficult negotiations on the Proposal, the idea arose to support the Commission momentum with a timely EU project under the then Agis programme: Status Quaestionis: Questionnaire on the Provision of Legal Interpreting and Translation in the EU (AGIS project JLS/2006/AGIS/052). ${ }^{9}$ This elaborate survey on LIT in the Member States showed that sufficient LIT skills and structures were not yet in place throughout the EU and, secondly, that although a process of development was in progress, it was still too variable in quality and quantity.

As could be expected, the responses to the proposed Framework Decision were once again quite diverse. Some Member States, the EU Parliament and in particular its important Civil Liberties Committee and, of course, the Commission itself, were supportive of the Proposal because it strengthened mutual cooperation and trust and greater compliance with the Convention. Other stakeholders (Amnesty International, the European Criminal Bar Association [ECBA], the LIT community, etc.), although disappointed because the Proposal was seen as a step back from the Green Paper, supported it because it at least laid down some minimum standards regarding procedural safeguards in criminal proceedings. But the old arguments that the Convention and its concomitant ECtHR case law were sufficient, that the Proposal contravened the subsidiarity principle and that it would lead to a national legislation muddle and an increase of costs, ultimately carried the day. As far as LIT was concerned, one can imagine that some Member States balked at Article 9 (to record and archive all interpreting in court) and Article 16 (the collection of data). In the end, after negotiations which dragged on from 2004, six Member States remained opposed and the Proposal was finally shelved in June 2007.

The real breakthrough came with the Stockholm 'Roadmap' (2009) strategy, an initiative of the Swedish EU presidency ( $1^{\text {st }}$ half 2009) to develop a Roadmap for strengthening procedural rights of suspected or accused persons in criminal proceedings, adopted by the Council on 30 November 2009. ${ }^{10}$ It identified proposals on five legislative measures - the right to interpretation and translation; the right to information about rights (the 'Letter of Rights'); the right to legal advice and legal aid; the right for a detained person to communicate with family members, employers and consular authorities; and the right to protection for vulnerable suspects - but it proposed to do so on a step by

\footnotetext{
9. Available on www.eulita.eu

10. Brussels, 18 September 2009. 13235/09. Droipen 93. Copen 166. Published Official Journal of the European Union, 4.12.2009. See http://eur-lex.europa.eu/LexUriServ/ LexUriServ.do?uri=OJ:C:2009:295:0001:0003:EN:PDF

See also http://www.eujusticia.net/index.php/proceduralrights
} 
step basis. This meant breaking up the huge package of procedural safeguards into manageable bits - the 'saucissonage' strategy - and since so much work had already been done on LIT and the feeling existed that it might be the 'easiest' of the safeguards for which to get unanimous approval fairly quickly, the Council agreed to put forth as a first legislative proposal a new Proposal for a Framework Decision on the right to interpretation and translation in criminal proceedings (Brussels, 8.7.2009, $\operatorname{COM}(2009) 338$ final. 2009/0101 (CNS). ${ }^{11}$

A comparison of the two proposed framework decisions shows that the new Proposal was definitely an improvement on the earlier one. For instance, it again included the right to interpretation during police questioning and all necessary meetings between the suspect and his lawyer but also in proceedings for the execution of a European Arrest Warrant. This time the right of appeal against a decision finding that there is no need for interpretation was explicitly mentioned. As for translation, Article 3 now listed the essential documents that always needed to be translated and the fact that Member States needed to ensure that there is a right of appeal against a decision to refuse the translation of such documents. Article 5 on the quality of interpretation and translation, however, again remained vague ("Interpretation and translation shall be provided in such a way as to ensure that the suspect is fully able to exercise his rights"), though it included in the same article the need for "training to judges, lawyers and other relevant court personnel in order to ensure the suspect's ability to understand the proceedings". Of course, Articles 9 and 16 of the earlier Proposal, which stirred so much opposition, were gone. Although definitely a step forward, this Proposal too was, fortunately enough, not the final word.

While negotiations on the new Proposal were under way, on the $1^{\text {st }}$ December of 2009, the Treaty of Lisbon was signed, amending the earlier treaties on the EU. For our purposes the following articles are crucial: Article 2 establishing the area of freedom, security and justice; Article 6 recognising that the Charter of Fundamental Rights of the European Union shall have the same legal value as the treaties, and that the EU as a political entity, and not only its Member States individually, shall accede to the European Convention for the Protection of Human Rights and Fundamental Freedoms and that these rights shall constitute general principles of EU law. Furthermore, the European Parliament and the Council can become co-legislators in virtually all areas of civil and criminal justice matters, with Article 9. 3. stating that "The Council shall act by a qualified majority except where the Treaties provide otherwise", thus

11. http://eur-lex.europa.eu/LexUriServ/LexUriServ.do?uri=COM:2009:0338:FIN:EN:PDF 
allowing for far greater flexibility than previously possible when unanimity was required in matters of justice. Given this new context, a number of Member States, with the support of the Commission and the Parliament, decided in March 2010 to re-submit the Proposal for a Framework Decision (the legal instrument available until then in matters of Justice) as a directive, the legal measure now at their disposal and one that would ensure that its provisions would have to be implemented in the legislation and procedural practices of the Member States.

\section{Directive 2010/64/EU}

It is difficult to overestimate the importance of Directive 2010/64/EU of the European Parliament and of the Council of 20 October 2010 on the right to interpretation and translation in criminal proceedings. ${ }^{12}$ It is the first directive under the Lisbon Treaty, the first directive in the field of Justice, the first directive on language since the founding treaties of the $\mathrm{EU}$ and, of course, the first directive on issues of translation and interpretation. In the following section we will present the articles of Directive 2010/64/EU under four main subheadings, thus highlighting at the same time the challenges the Member States face when transposing the Directive into national legislation and administrative provisions.

\subsection{The Rights Challenge}

Article 1. Subject matter and scope

The right to interpretation and translation applies to criminal proceedings as well as - very explicitly - to proceedings for the execution of a European Arrest Warrant. LIT has to be provided from the time one is made aware by the competent authorities of a Member State that one is suspected or accused of having committed a criminal offence until the conclusion of the proceedings, i.e. until res judicata. In other words, the Directive does not apply to post-trial situations (such as probation or prison) though it does apply from the moment any action is taken against someone who is suspected or accused of having committed a crime, such as an arrest or a search warrant. In these cases LIT has to be provided without delay. However, the right does not apply to situations of minor offences (i.e. which are settled out-of-court such as

12. Official Journal of the European Union, L 280/1, 26.10.2010.

http://eur-lex.europa.eu/LexUriServ/LexUriServ.do?uri=OJ:L:2010:280:0001:0007: en:PDF 
traffic violations), unless the offence at some later stage enters proceedings before a court.

Article 2. Right to interpretation

1. Without delay, during police questioning, all court hearings and any necessary interim hearings;

2. Interpretation must also be available for communication between suspected or accused persons and their legal counsel, a provision now in line with the important 'Salduz' arrest of 27 November 2008 of the ECtHR in Strasbourg, ${ }^{13}$

3. The right includes appropriate assistance for persons with hearing or speech impediments which affect their ability to communicate effectively. The prosecution, law enforcement and judicial authorities should ensure that such persons are able to exercise the rights effectively, for example by taking into account any potential vulnerability that affects their ability to follow the proceedings and to make themselves understood. In this context it is important to realize that, generally speaking, when an EU law, in this case the Directive, provides an individual right, it has to come with an effective remedy in case of non-compliance;

4. A procedure or mechanism to ascertain whether suspected or accused persons speak and understand the language of the criminal proceedings and whether they need the assistance of an interpreter. Interpretation (as well as translation; see Art.3) should be provided in the native language of the suspected or accused persons but could also be provided in any other language that they speak or understand. However, great care needs to be taken here (particularly by defence lawyers) that the problems ensuing from languages of lesser diffusion are not offhandedly dealt with. The rights of defence and the fairness of the proceedings must be safeguarded;

5. The right to challenge a decision finding that there is no need for interpretation and the possibility to complain that the quality of the interpretation is not sufficient. When the quality of the interpretation is considered insufficient to ensure a fair trial, the competent authorities should be able to replace the appointed interpreter;

6. Videoconferencing, telephone or the internet may be used unless the physical presence of the interpreter is required in order to safeguard the fairness of the proceedings;

13. http://hudoc.echr.coe.int/ 
7. In proceedings for the execution of a European Arrest Warrant which, by definition, involve more than one Member State.

Article 3. Right to translation

1. A written translation of all documents which are essential. Another instance where the Directive goes further than the ECHR because the documents are explicitly identified: any decision depriving a person of his liberty, the charge or indictment, and the judgment. These documents must be provided within a reasonable period of time, in any case avoiding a delay that would make further procedural steps, such as an appeal, impossible;

2. Any other document which is essential. This will usually happen at the request of defence counsel and will be for the presiding judge to rule on;

3. The right to challenge a decision finding that there is no need for the translation of documents or passages thereof and the possibility to complain that the quality of the translation is not sufficient;

4. As an exception, an oral translation or oral summary of essential documents may be provided instead of a written translation on condition that this does not prejudice the fairness of the proceedings. National legislation or procedural practice will have to lay down and state the reasons for such exception(s). Usually this will be at the discretion of the presiding magistrate or judge but the Directive explicitly suggests it should be an exception and stresses the caveat that it must not jeopardize the fairness of the proceedings;

5. Any waiver of the right to translation must be subject to prior legal advice and in the full knowledge of the consequences of such a waiver, and the waiver must be unequivocal and voluntary. These are stringent conditions, and different from the right to interpretation where no such waiver of one's right is possible;

6. The executing Member State shall ensure that any person who does not understand the language in which the European Arrest Warrant is drawn up, or into which it has been translated by the issuing Member State, is provided with a written translation.

\subsection{The Cost Challenge}

Article 4. Costs of interpretation and translation

"Member States shall meet the costs of interpretation and translation resulting from the application of Articles 2 and 3, irrespective of the outcome of the proceedings". 


\subsection{The Quality Challenge}

Article 2.5.

"[... W] hen interpretation has been provided, the possibility to complain that the quality of the interpretation is not sufficient to safeguard the fairness of the proceedings."

Article 2.8.

"Interpretation shall be of a quality sufficient to safeguard the fairness of the proceedings, in particular by ensuring that suspected or accused persons have knowledge of the case against them and are able to exercise their right of defence."

Articles 3.5. and 3.9.

When a translation has been provided, "the possibility to complain that the quality of the translation is not sufficient to safeguard the fairness of the proceedings";

Translation "shall be of a quality sufficient to safeguard the fairness of the proceedings".

\section{Article 5}

1. "Member States shall take concrete measures to ensure that the interpretation and translation provided meet the quality required under Article 2(8) and Article 3(9)." It is left to the Member States to decide what these quality measures should be, but they have to be demonstrable and concrete. It also seems to imply that the responsibility to ensure quality ultimately lies with the Member States, even if they procure the services of an external agency;

2. "In order to promote the adequacy of interpretation and translation and efficient access thereto, Member States shall endeavour to establish a register or registers of independent translators and interpreters who are appropriately qualified." Although "shall endeavour" may sound rather weak, it does mean that Member States must demonstrably show how they have implemented the requirement of a register that guarantees 'adequacy' and 'quality' of translation and interpretation. Common sense dictates that one cannot be qualified unless one is trained. But this crucial requirement has been left disappointingly vague and the fact that such registers, once established, shall be "made available", "when appropriate" 
to legal counsel and relevant authorities instead of compulsory (with a possible protocol in case of emergency or impossibility) is another weak point. Moreover, what is puzzling is the use of the word 'independent' in the Article. Is it an implied reference to section 5.3. and the issue of 'confidentiality' and are both sections to be read as a requirement for LITs to abide by a code of conduct, or is it to be interpreted as an instruction not to use other legal professionals (such as police officers or lawyers ) as interpreters? Perhaps maximizing the potential of this constructive ambiguity by applying both interpretations would be the best course to follow for the Member States;

3. Member States shall ensure that interpreters and translators be required to observe confidentiality regarding interpretation and translation. This would seem to imply a binding code of conduct or ethics for LITs, with accompanying disciplinary procedures in case of breaches of the code.

\subsection{The administrative challenges}

Article 6

"Member States shall request those responsible for the training of judges, prosecutors and judicial staff involved in criminal proceedings to pay special attention to the particularities of communicating with the assistance of an interpreter so as to ensure efficient and effective communication." This is an interesting requirement which, strangely enough, leaves out key stakeholders such as defence lawyers and, of course, the LITs themselves.

\section{Article 7}

Member States are required to keep records of the interpretation or translation assignments, using a recording procedure in accordance with the law of the Member State concerned.

Article 9

"Member States shall bring into force the laws, regulations and administrative provisions necessary to comply with this Directive by 27 October 2013."

Article 10

"The Commission shall, by 27 October 2014, submit a report to the European Parliament and to the Council, assessing the extent to which the Member 
States have taken the necessary measures in order to comply with this Directive, accompanied, if necessary, by legislative proposals."

\section{The transposition}

Strictly speaking, in the short-term, the Member States needed to adapt national legislation and administrative provisions to the requirements of the Directive by 27 October 2013 and submit a report to the Commission on their transposition measures by 27 October 2014. The national provisions communicated to the Commission by the Member States concerning the Directive can be consulted on the EUR-Lex Archive site. ${ }^{14}$ At the time of writing (June 2014), there is no information as yet available on Belgium, Spain, Portugal and Slovakia while all other Member States have filed references to legislative implementation measures. In Germany, as one can see, there is now a new Gesetz zur Stärkung der Verfahrensrechte von Beschuldigten im Strafverfahren vom 2. Juli 2013; in France, the Décret no 2013-958 du 25 octobre 2013 portant application des dispositions de l'article préliminaire et de l'article 803-5 du code de procédure pénale relatives au droit à l'interprétation et à la traduction; in the Netherlands there is the Wijziging van het Wetboek van Strafvordering ter implementatie van richtlijn 2010/64/EU (vertolking en vertaling) van 12/03/2013; and in Sweden, the Lag om ändring i lagen (1975:689) om tystnadsplikt för vissa tolkar och översättare. Svensk författningssamling, 2013:664. ${ }^{15}$

It is beyond the scope of this article to analyse in any detail the substance of all these national legislative initiatives in the Member States. They do reveal an interesting range of transposition policies and strategies, from a minimum minimorum to a truly substantial approach adhering to both the letter and the spirit of the Directive. Ultimately, all national measures will have to stand the test of the Commission's interpretation of the Directive. The simple fact of the matter is that EU legislation needs to be abided by. If not, financial penalties can be imposed for not meeting a transposition deadline. By the end of 2014, the transitional phase set out in the Lisbon Treaty for the area of justice will

14. http://old.eur-lex.europa.eu

15. The absence of information on the site does not automatically mean there are no initiatives. One may simply not have communicated them at this stage. In Belgium, for example, there is a bill before parliament (DOC 53 1499/006 of 14 February 2014) envisaging the establishment of a register of forensic experts and a second, separate one of LITs, with important differences in the admission and competences criteria. LITs will need to have a 'relevant' degree (not specified) or two years of relevant experience. They will have to pass a test on 'legal knowledge' only, with a five-year transition period. 
end and will lift current judicial limitations to the Commission's role as guardian of the Treaty also in the area of police and judicial cooperation in criminal matters, meaning the Commission will have the power to launch infringement proceedings against a Member State in case of non-compliance with the Directive. Additionally, some extra pressure can be brought on Member States by means of the EU Justice scoreboard, a comparative tool which provides information on the justice systems in the Member States and in particular on the quality and efficiency of justice. There can be no doubt that the degree of compliance with this Directive will also figure on this 'naming and shaming' league table. ${ }^{16}$ However, it is an illusion to think that in most Member States the transposition of the Directive will change the LIT landscape overnight. The core concepts and objectives of the Directive concern 'quality'. This will and cannot be achieved by simply substituting all and sundry LIT lists which circulate locally, regionally, on a police officer's or court clerk's desk for a new national register.

Therefore, we need to take a long(er)-term perspective to survey which steps should be taken to ensure that the objectives that are envisaged in the Directive are really and fully implemented.

\section{Step 1: Establish a working group on LIT}

Data should be collected, analysed and disseminated by a working group consisting of all relevant stakeholders as a basis for nationally or regionally co-ordinated and informed planning in order to meet the requirements with regard to LIT and later on to monitor incremental development and progress.

Interesting data would relate to current demand in terms of legislation relating to LIT, number of criminal cases employing LITs, budget allocated and spent on LIT, when an interpreter or translator is engaged and with what qualifications, in which language, in which geographical location, where qualified LITs were needed but none were available because e.g. none exist in the language/dialect required or for reasons of distances or time constraints, etc. On the other hand, it would be useful to draw up a status quaestionis of current supply of qualified LITs in terms of numbers, languages, qualifications, registration, membership in a professional body, available training, numbers currently in training, qualifications of trainers, in which languages and locations, available CPD and whether a quality monitoring system is in place or not.

16. http://ec.europa.eu/justice/effective-justice/files/justice_scoreboard 
Step 2: Develop an overall strategy and quality chain in LIT

Two documents could be helpful in this respect: the EU Resolution and the Reflection Forum Report.

The Proposal for a Resolution of the Council and of the Governments of the Member States meeting within the Council fostering the implementation by Member States of the right to interpretation and to translation in criminal proceedings sets out a comprehensive strategy to implement quality LIT in the Member States. ${ }^{17}$ These are some of its relevant recommendations:

(5) Member States should ensure that professional bodies representing accredited/certified interpreters and translators are in place.

(6) Member States should organise appropriate training structures for interpreters and translators.

(7) Member States should have a system of continuous professional development.

(9) Member States should ensure that there is a system of accreditation/ certification for interpreters and translators who can be employed in criminal proceedings.

(10) Member States should ensure that there is a system of registration for accredited/certified interpreters and translators.

(15) Member States should ensure that only accredited/certified interpreters and translators carry out interpretations.

(17) In situations where it is appropriate, interpretation could be provided by a certified/accredited interpreter at a remote location, for example by using videoconference facilities.

(20) Member States should ensure that there is a Code of Conduct for interpreters and translators, as well as Guidelines for Good Practice.

(22) Member States should ensure that there is a mechanism for evaluation of the systems aiming to ensure the quality of interpretation and translation given in criminal proceedings.

A second useful document is the report of the Reflection Forum on Multilingualism and Interpreter Training. ${ }^{18}$ In spite of its title, this report focuses explicitly on LIT and contains, very much in line with the Resolution, interesting recommendations to the Member States.

17. Brussels, 15 July 2009, Council of the European Union, 12116/09, DROIPEN 66, COPEN 139.

See http://register.consilium.europa.eu/doc/srv?l=EN\&f=ST\%2012116\%202009\%20INIT

18. http://www.eulita.eu, where the report can be consulted in EN, FR, DE and SP 
Recommendation I

- The legal services and professionals should recognize the professional profile of the legal interpreter and translator.

Recommendation II

- Member States should provide appropriate training both for new and already practising legal interpreters and translators;

- Such training should lead to a nationally recognized professional certification and be accredited by a recognized authority;

- Efforts should be made to develop equivalent training throughout the EU to ensure mutual trust and cooperation.

Recommendation III

- The Professional Code of Conduct and the Guidelines to Good Practice should be an integral part of the training.

Recommendation IV

- A national register of qualified legal interpreters should be kept, and the use of only registered legal interpreters made mandatory.

- The national registers should aim for EU consistency, thus allowing mutual access.

Step 3: Implement available good practice information on the Directive

In order to assist all relevant legal stakeholders as well as LIT associations and training institutes during the implementation process, the TRAFUT (Training for the Future) project (Criminal Justice Programme project JUST/ JPEN/AG/1549) organised four workshops that were held throughout the EU in the course of 2011 and 2012. Experts from DG Justice and the Secretariat of the EU Council, from the European Court of Justice, the ECtHR, the European Criminal Bar Association, the Council of Bars and Law Societies in Europe, and the European Forum of Sign Language Interpreters, along with judges, prosecutors, lawyers, police officers, representatives of ministries of Justice and of national LIT associations, academics and trainers, all discussed good practice models and strategies to achieve a coherent management and implementation process of the Directive. All presentations are available on the EULITA website. ${ }^{19}$ Collectively, these presentations contain useful material, for instance on:

- the background and overall objectives of the Directive and the challenges of its transposition into national legislation; the extent to which

19. http://www.eulita.eu 
its principles and articles meet or go beyond the landmark decisions on translation and interpretation of the ECtHR;

- the issue of cost, including the problems that arise from ill-considered outsourcing and procurement;

- the issue of quality in LIT, with the views and expectations of service providers (e.g. the courts or the police), the users (e.g. lawyers or probation officers) as well as LIT trainers;

- the issue of national registers of LITs: admission procedures, qualifications, register management, etc., including the future integration of Member States' registers into an EU LIT database, as envisaged in the e-Justice portal;

- the training of both legal professionals and LITs, good practice models for effective communication and working arrangements;

- modern communication technologies in criminal proceedings such as video-link interpreting and the issue of appropriate assistance for vulnerable persons.

\section{Step 4: Establish training in LIT}

Common sense suggests that in matters as serious as acquittal or conviction, fair trial or victims' support, one would not want to rely on untrained, inexperienced, unqualified LITs. No one would put their trust in the hands of a defence counsel dragged in from the street or would submit to an interview by an 'ad hoc' police officer. Therefore, it is obvious that the requirement in the Directive to ensure quality LIT implies that the LITs themselves have been properly trained. The Directive does not explicitly mention training of LITs (it refers to training in Article 6 for legal professionals only) probably because it was felt that the emphasis on quality implied the need for training. Perhaps it was felt to be beyond the remit of DG Justice (and a matter of professional education and qualifications) ${ }^{20}$ It is also the case that the ECtHR in its deci-

20. Nevertheless: "Training of legal translators and interpreters was widely recognised both as necessary and as specific to answer their need for knowledge of the peculiarities of the different judicial systems and of European legal vocabulary. Some indicated that their training could be considered as part of European judicial training as such. In view notably of the Directive on the right to interpretation and translation in court proceedings, a proper understanding by legal translators and interpreters is necessary and would contribute to the expedient conduct of proceedings (and thus to a reduction in litigation costs). One focus of this training could be on the interaction between legal interpreters and translators on the one hand, and judges, prosecutors, judicial staff, and lawyers on the other hand." European Commission 2010 Consultation on European Judicial Training (Ref. Ares (2011) 413544 - 13/04/2011). 
sions has consistently shied away from defining the issue of quality and the professional qualifications of LITs.

At the moment there are sufficient models available for training and it is for the stakeholders in any particular Member State to decide which would be the best option for them. It may be that some academic institutions will take the initiative and offer a B.A. or an M.A, either in 'community' or 'public services' interpreting and translation, hence wider than legal only, or even a specific LIT programme. Such academic programmes have clear advantages, such as the possibility of selecting students (on the basis of degrees or previous education), staff expertise, appropriate infrastructure, a certain thoroughness and depth of learning, a grounding in supporting and related subjects. And importantly, they lead to recognised certification and accreditation. On the other hand, these institutions by necessity can offer only a limited range of languages, there is the risk of a lack of specific LIT competences in a broader curriculum and the academic staff may not always possess the necessary practical experience; the selection of students is based on official qualifications rather than background, or experience, or indeed on the needs of the country or region; and finally, as one knows, convincing academic authorities to introduce a new curriculum is a Herculean task.

One might therefore, in addition to or in conjunction with the academic stream or else independently, opt for professional/vocational training programmes. It is important they be offered by a trustworthy institution (be it academic, educational or judicial) and that the certification of graduates, after valid and reliable testing, be authorised by the official national or regional authority responsible for accreditation. Such programmes are usually evening and weekend classes, increasingly making additional use of distance learning and range on average between 120 and 220 hours. The advantages are that the selection of students is not rigidly degree-based but can be done, for example, on the basis of a national and foreign language(s) proficiency tests (if so desired with an additional aptitude and motivation interview), that the course is not hampered by strict academic curriculum regulations but can be run language-independent and/or language-specific. Such programmes allow more flexible involvement of stakeholder trainers (from the courts, the Bar, the police, etc.) and can be run at potential low cost if one can convince the authorities of these stakeholders to invest staff time in the programme because qualified LITs simply allow them to do a better job. Perhaps the main advantage is that one can respond much more directly and quickly to the language needs in a particular country or region, given that any top ten of 
languages (which will almost certainly not be the ones taught in higher education) covers roughly $80 \%$ of the needs in criminal proceedings.

But whichever format one chooses, any LIT programme will revolve around a number of core competencies to be acquired. These competencies will have to be trained in a curriculum that would probably contain all or most of the following modules:

- Module 1: Introduction to LIT, state of the art in the EU and the national practice.

- Module 2: Resources and information retrieval in LIT.

- Module 3: Language issues: legal language, terminology, discourse and pragmatics, the range of registers most commonly used in the legal contexts, genre-studies.

- Module 4: Knowledge of the legal system(s): structures, procedures, processes and personnel; knowledge of the relevant aspects of criminal and civil law, the main settings, augmented by observation visits, internships.

- Module 5: Interpreting/Translation theory, skills and strategies.

- Module 6: Professional Code of Conduct and Guidelines to Good Practice.

- Module 7: Integrated interpreting/translation skills through case studies, role plays, mock courts, translation assignments, etc.

- Module 8: Professional issues: awareness of the national professional association(s), working arrangements with legal professionals, how to accept and prepare for assignments, potential health and safety issues, time, diary and financial management, the need for continuous professional development, etc.

There is, of course, a considerable body of literature on the training of LIT but within the context of DG Justice Action Grants only, a number of interesting EU projects on LIT such as Aequitas, Building Mutual Trust 1 and 2, the IMPLI project on interpreted police interviews, Qualitas on the assessment and testing of legal interpreting competences and Qualetra on legal translation, provide a wealth of materials.

\section{Step 5: Videoconferencing}

Given the mention of videoconference and other forms of remote interpreting (telephone, internet) in the Directive, its increasing use by police and judicial authorities in both national (e.g. for security reasons or to avoid transporting 
prisoners to a perfunctory hearing) and EU contexts (e.g. the hearing of a witness or victim abroad), as well as the importance attached to it in the e-Justice programme, LIT training programmes should pay due attention to the specific requirements of this mode of interpreting. ${ }^{21}$ We refer the reader here to the e-Justice site and to the research and results of two completed EU Avidicus projects on interpreted videoconferencing in criminal proceedings. ${ }^{22}$

\section{Step 6: Registers}

One of the aims of training and certification is the establishment of a register of qualified LITs and the use by the police and judicial services of 'appropriately qualified' LITs only. As said above, there will always be emergencies when a specific language/dialect requirement cannot be met by a trained LIT within the legal time framework available, but in these cases a protocol should be drawn up explaining the actions taken and reasons why. A thorough pre-briefing should be held and an appropriate interviewing style adopted in order to minimize the problems possibly resulting from the emergency situation. But gradually and over time it should become established practice to use only LITs who are qualified and are on the official register. EULITA has drawn up initial guidelines for the concept and content of such registers including the legislation applicable to a (national/regional) register; the scope of application of the register (courts, police, immigration...); the admission procedures; the general requirements (nationality, age, absence of criminal record, security vetting...); the specific requirements (languages, translation and /or interpreting, training, experience, specialisation[s]...); the requirements for entry into the register (oath, seal, code of conduct...); duration and renewal of registration; complaints and disciplinary procedures; the accessibility of the register (courts, police, lawyers, general public...); the administrative management of the register. ${ }^{23}$

Such a national register has the additional advantage of being a step on the road to an EU-wide register of LITs, which would allow for the trustworthy use of an LIT in e.g. European Arrest Warrant proceedings, rogatory commissions or remote interpreting situations. As a matter of fact, the working party on e-law (e-Justice) supports harmonizing LIT databases on common standards in equivalent national registers to enhance mutual cooperation

21. https://e-justice.europa.eu/content_videoconferencing

22. http://www.videoconference-interpreting.net/

23. http://eulita.eu/antwerp-programme 
throughout the EU. ${ }^{24}$ A DG Justice project - LIT search (JUST/2013/JPEN/ AG/4556) - is exploring the necessary steps and parameters to arrive at such an EU-wide LIT register.

A final advantage of an official register is that it offers an opportunity to do away with all sorts of informal and personal lists of LITs who have perhaps (or most likely) never been trained or tested and who continue to feed a certain perception of LITs among other legal professionals that does not do justice to what a properly trained and qualified LIT does. Therefore, training should also be offered to all the 'ad hoc' LITs presently on these lists but the principle must remain that in the end no one is allowed onto the official register who has not been tested and certified.

\section{Step 7: Manage the costs of LIT}

Providing LIT services in criminal proceedings entails a considerable cost and certainly in times of budgetary crisis this is, understandably, a worrying concern for all Member States. When the EU Commission presented its 2009 impact study referred to above, for the Netherlands the cost was estimated at $€ 10,718,400$ for interpreting and between $€ 13,665,980$ and $€ 80,388,000$ for translation, whereas in 2010 the actual total cost for LIT amounted to $€ 34,946,000$. In Belgium, the cost for interpreting was estimated at $€ 3,725,600$ and between $€ 4,750,140$ and $€ 27,942,000$ for translation whereas the actual total cost in the year of the impact study (2009) was $€ 17,772,730$. In 2010 the sum total had risen to $€ 24,916,672$. An extra $€ 5,547,315$ was spent on transcribing and translating wire-taps, a dramatic increase by $77 \%$ compared to 2009.25

These are considerable expenditures - and still rising -, and costs are a real concern. Service providers are therefore looking into better management of travel and waiting time of interpreters, the use of technology (video-links, telephone interpreting hubs, etc.), the promotion of terminology databases, translation memories, etc., to reduce time spent on translation, a greater expertise of LITs employed in special assignments (e.g. re-transcribing and re-translating a long bungled wire-tap is an astronomically expensive business), etc. This poses a double challenge to training institutes as well as professional associations. They need to bring these skills (e.g. remote interpreting or translation memory competences) into their training and actively

\footnotetext{
24. e-Justice document 13949/12 of 27 September 2012 on 'Translators and interpreters databases' and 'find a legal translator or interpreter' on https://e-justice.europa.eu

25. http://www.cmro-cmoj.be/sites/default/files/files/gerechtskosten_2010_NL.pdf
} 
engage in negotiations with the authorities on these cost-cutting strategies. If they do so, they will at least have a chance to defend the principle that there can be no compromise on quality. All too often these days Member States turn to outsourcing of LIT services, committing the unforgiveable sin of letting the control of quality, remuneration of the LITs and ultimate responsibility for the service slip out of their hands, with disastrous consequences in every case where one has gone down that road. The authorities need to be assured over and over again that quality of LIT allows everyone to do a better job, that it minimizes the risks of miscarriages of justice, avoids appeals or convictions in 'Strasbourg', and that it safeguards fundamental human rights which each one of us at some point may stand in dire need of.

Step 8: Involve all relevant legal professions in training and in good practice working arrangements

Training institutes and LIT associations can play an important role in fostering awareness of LIT and good practice working arrangements with legal professionals. Some strategies seem self-evident: legal professionals could be invited to teach in the training programmes; training institutes could offer to teach a (shorter or longer, compulsory or optional) module on justice across languages and cultures to Law Faculty students; legal professional associations (of judges, lawyers, police...) could be approached to put LIT issues on their CPD agenda. Furthermore, materials could be distributed such as the recommendations from various EU projects (e.g. Aequitas [Chapter 9], Building Mutual Trust 1 [Chapter 9], the Avidicus projects' recommendations on remote interpreting, Building Mutual Trust 2 and the IMPLI project on interpreted police interviews). There are the Guidelines for a more effective communication with legal interpreters and translators, a joint project of EULITA and ECBA (European Criminal Bar Association), available on www.eulita.eu, and the Guide to Roadmap Rights of Fair Trials International (www.fairtrials. net), and indeed the many examples of good practice available in various Member States.

Once again, the important point is for all stakeholders to be (or become) aware of the fact that the Directive sets new, binding standards. Judges, as the ultimate guardians over the proceedings in their courts, are now bound by this EU law taking precedence over national law. Police officers as well as lawyers should from now on make sure that in their dealings with suspects, defendants, witnesses or victims, the quality of their work is not imperilled by deficient interpreting or a sub-standard translation. 


\section{Beyond Directive 2010/64/EU}

In the area of criminal justice, fundamental rights and access to justice have been further strengthened by progressively expanding the set of fair trial rights. On 22 May 2012, Directive 2012/13/EU of the European Parliament and of the Council on the right to information in criminal proceedings was adopted ${ }^{26}$ and in October 2013 Directive 2013/48/EU on the right of access to a lawyer in criminal proceedings and on the right to communicate upon arrest was passed. ${ }^{27}$ Another directive which is relevant in this context is Directive 2012/29/EU establishing minimum standards on the rights, support and protection of victims of crime. ${ }^{28}$ All three directives contain articles on the provision of translation and interpretation which should be provided in accordance with the quality standards required by Directive 2010/64/EU. For instance, Article 7 of the Directive on victims' rights ensures that victims who do not understand or speak the language of the criminal proceedings concerned are to be provided with interpretation "free of charge, during any interviews or questioning of the victim during criminal proceedings". They have the right to challenge a decision finding that there is no need for interpretation or translation and the possibility to complain that the quality of the interpretation is not sufficient to exercise their rights or understand the proceedings. When appropriate, "communication technology such as videoconferencing, telephone or internet may be used, unless the physical presence of the interpreter is required in order for the victim to properly exercise their rights or understand the proceedings". Furthermore,

[a] victim who does not understand or speak the language of the criminal proceedings concerned shall receive translations free of charge of (a) the complaint of the criminal offence to the competent authority; (b) any decision ending the criminal proceedings related to the criminal offence reported by the victim including at least a summary of the reasons for such a decision; and (c) information essential to the victim's exercise of their rights in criminal proceedings in accordance with their needs and their role in those proceedings. (Directive 2012/29/EU, Art. 6.4)

26. Official Journal of the European Union, 1.6.2012. http://eur-lex.europa.eu/legal-content/EN/TXT/?uri=OJ:L:2012:142:TOC

27. Official Journal of the European Union, 6.11.2013. http://eur-lex.europa.eu/legal-content/EN/TXT/?uri=uriserv:OJ.L_.2013.294.01.0001. 01.ENG

28. Official Journal J L 315, 14/11/2012. http://eur-lex.europa.eu/legal-content/en/TXT/?uri=CELEX:32012L0029 
The constant references to and inclusion of the fundamental principles of Directive 2010/64/EU in all related criminal proceedings legislative instruments goes to show how crucial this particular directive is in safeguarding fair trial rights. New proposals for directives on the strengthening of certain aspects of the presumption of innocence and of the right to be present at trial in criminal proceedings, on procedural safeguards for children suspected or accused in criminal proceedings will further strengthen the bedrock upon which EU justice policy is built.

The end of 2014 marks a turning point in the development of EU Justice policy. The European Council's five-year Stockholm Programme and the related Commission Action Plan of priorities in the area of freedom, security and justice - one of the EU's objectives of the Treaty of Lisbon - will come to an end. After two years of negotiations, a new Justice Programme and a new Rights, Equality and Citizenship Programme were adopted by the European Parliament and the Council, with their accompanying Action Plans and budgetary provisions. ${ }^{29}$ However, the principles enshrined in Directive 2010/64/EU will surely continue to be the point of reference for all matters of translation and interpretation in criminal proceedings. There can also be no doubt that over time its principles will come to guide practice in civil proceedings, for example in mediation or alternative dispute resolution, in post-trial proceedings such as probation or in other legal settings like asylum hearings or detention centres. Whatever its shortcomings, Directive 2010/64/EU of the European Parliament and of the Council on the Right to Interpretation and Translation in Criminal Proceedings offers all authorities, legal professionals, LITs, LIT training institutes and professional associations a unique legal instrument to work with to ensure quality of translation and interpreting in criminal proceedings. At the same time, it presents them with a formidable challenge and responsibility. But that Directive 2010/64/EU is a landmark, a milestone, of this there can be no doubt.

29. Regulation (EU) $n^{\circ} 1382 / 2013$ of the European Parliament and of the Council of 17 December 2013 establishing a Justice Programme for the period 2014 to 2020 and Regulation (EU) $n^{\circ} 1381 / 2013$ of the European Parliament and of the Council of 17 December 2013 establishing a Rights, Equality and Citizenship Programme for the period 2014 to 2020. 


\section{BIONOTE / NOTA BIOGRÁFICA}

Erik Hertog is Emeritus Professor of Cultural Studies and both Conference and Public Services Interpreting Studies in the Faculty of Arts, KU Leuven in Antwerp, Belgium. In the field of legal interpreting, he has coordinated many policy projects for the Antwerp courts and police and the Ministry of Justice of the Netherlands, among others. He has coordinated many Grotius, Agis and Criminal Justice projects of the DG Justice of the EU Commission. For instance, he was the coordinator of the project establishing EULITA, the EU Association of Legal Interpreters and Translators, and is currently a participant in the Avidicus projects on video-link interpreting in criminal proceedings, the Qualitas project (on assessment and testing of legal interpreting), the Qualetra project (idem for legal translation), and the SOS-VICS project on the support of victims of gender violence in interpreted encounters. He also acted as rapporteur of the Reflection Forum on Multilingualism and Interpreter Training for the EU Commissioner of Multilingualism.

Erik Hertog es profesor emérito de Estudios Culturales, así como de Estudios de Interpretación de Conferencias y en Servicios Públicos, de la Facultad de Letras de la Universidad Católica de Lovaina en Amberes, Bélgica. En el ámbito de la interpretación judicial ha coordinado muchos proyectos de elaboración de políticas, entre los que se incluyen los desarrollados para los juzgados y la policía de Amberes, así como para el Ministerio de Justicia de los Países Bajos. Ha coordinado también numerosos proyectos Grotius, Agis y de Justicia Penal, pertenecientes a la Dirección General de Justicia de la Comisión Europea. Fue, por ejemplo, el coordinador del proyecto para la creación de EULITA, la Asociación de Intérpretes y Traductores Judiciales de la UE. En la actualidad participa en el proyecto Avidicus sobre interpretación por videoconferencia en los procesos penales, en el proyecto Qualitas (sobre evaluación y acreditación de intérpretes judiciales), en el proyecto Qualetra (igual que el anterior pero sobre traducción judicial) y en el proyecto SOS-VICS sobre asistencia a víctimas de violencia de género en encuentros con intérpretes. También fue relator del Foro de Reflexión sobre Multilingüismo y Formación de Intérpretes para el Comisario europeo de Multilingüismo. 